medRxiv preprint doi: https://doi.org/10.1101/2021.03.29.21254509; this version posted March 31, 2021. The copyright holder for this preprint (which was not certified by peer review) is the author/funder, who has granted medRxiv a license to display the preprint in It is made available under a CC-BY-NC-ND 4.0 International license .

\title{
Genetic associations with severe COVID-19
}

Nicholas M. Murphy, $\mathrm{PhD}^{1}$

Gillian S. Dite, $\mathrm{PhD}^{1 *}$

Richard Allman, $\mathrm{PhD}^{1}$

1. Genetic Technologies Ltd., Fitzroy, Victoria, Australia

* Corresponding author:

Gillian Dite

Genetic Technologies Ltd., 60-66 Hanover St, Fitzroy VIC 3065, Australia gillian.dite@gtglabs.com 
medRxiv preprint doi: https://doi.org/10.1101/2021.03.29.21254509; this version posted March 31, 2021. The copyright holder for this preprint (which was not certified by peer review) is the author/funder, who has granted medRxiv a license to display the preprint in It is made available under a CC-BY-NC-ND 4.0 International license .

\section{Abstract}

Identification of host genetic factors that predispose individuals to severe COVID-19 is important, not only for understanding the disease and guiding the development of treatments, but also for risk prediction when combined to form a polygenic risk score (PRS). Using population controls, Pairo-Castineira et al. identified 12 SNPs (a panel of 8 SNPs and a panel of 6 SNPs, with two SNPs in both panels) associated with severe COVID-19. Using controls with asymptomatic or mild COVID-19, we were able to replicate the association with severe COVID-19 for only three of their SNPs and found marginal evidence for an association for one other. When combined as an 8-SNP PRS and a 6-SNP PRS, we found no evidence of association with severe COVID-19. The difference in our results and the results of Pairo-Castineira et al. might be the choice of controls: population controls vs controls with asymptomatic or mild COVID-19. 
medRxiv preprint doi: https://doi.org/10.1101/2021.03.29.21254509; this version posted March 31, 2021. The copyright holder for this

preprint (which was not certified by peer review) is the author/funder, who has granted medRxiv a license to display the preprint in

It is made available under a CC-BY-NC-ND 4.0 International license .

\section{Paper}

Pairo-Castineira et al. ${ }^{1}$ identified 12 single nucleotide polymorphisms (SNPs) that were associated with critical illness in COVID-19, in particular a panel of 8 SNPs (associated with risk of intensive care admission) from independent genome-wide significant regions and a panel of 6 SNPs (associated with hospitalization) from a meta-analysis of overlapping SNPs between GenOMICC, Host Genetics Initiative and 23andMe studies (two of these SNPs were also in the panel of 8 SNPs). These SNP panels were identified and validated using population controls.

Using the UK Biobank, ${ }^{2-4}$ we evaluated the ability of the two SNP panels to predict severe COVID-19 - should a person become infected - when combined as PRSs. We downloaded the UK Biobank COVID-19 results file on 8 January 2021 and identified 8672 active participants with a positive SARS-CoV-2 test result, 8374 of whom had SNP data available. As we did previously, ${ }^{5}$ we used source of test result as a proxy for disease severity, with 2288 (27.3\%) participant results coming from an inpatient setting (cases) and 6086 (72.7\%) participant results coming from an outpatient setting (controls).

We used the estimates of the odds ratio (OR) per effect allele provided in PairoCastineira et al. ${ }^{1}$ to construct the 8-SNP and 6-SNP PRS (the meta-analysis ORs for the 6SNP PRS). For the SNPs in their Table 1 and the two overlapping SNPs from their Table 2, we used the GenoMICC risk allele frequencies provided, and for the remaining SNPs in their Table 2, we used allele frequencies from SNPnexus. ${ }^{6}$ For the construction of the PRS, ${ }^{7}$ we assumed independent and additive risks on the log OR scale. For each SNP, we calculated the unscaled population average risk $(\mu)$ as:

$$
\mu=(1-p)^{2}+2 p(1-p) O R+p^{2} O R^{2}
$$


medRxiv preprint doi: https://doi.org/10.1101/2021.03.29.21254509; this version posted March 31, 2021. The copyright holder for this

preprint (which was not certified by peer review) is the author/funder, who has granted medRxiv a license to display the preprint in

It is made available under a CC-BY-NC-ND 4.0 International license .

Next, for each SNP, adjusted risks (with a population average risk equal to 1) were calculated as:

adjusted_risk $=\frac{O R^{N}}{\mu}$, where $\mathrm{N}$ is the number of effect alleles.

The PRS was then calculated as the product of the adjusted risk values for each of the SNPs.

We first used logistic regression to estimate the unadjusted per allele effects for each SNP (see Table 1). Of the 12 SNPs, three (rs71325088, rs73064425, and rs9380142) were associated with severe disease and one (rs13050728) was marginally statistically significant using a nominal statistical significance of $\mathrm{P}<0.05$. These SNPs all had smaller effect sizes in our analysis compared with those reported in Pairo-Castineira et al. ${ }^{1}$ (rs71325088, OR=1.15 vs 1.9 , respectively; rs73064425, $\mathrm{OR}=1.17$ vs 2.1 ; rs9380142, $\mathrm{OR}=1.09$ vs 1.3 ; and rs13050728, OR=1.07 vs 1.2).

We then used logistic regression to estimate the OR per quintile of risk in the controls for the two PRS. While marginally statistically significant, these showed only a weak association with a $3 \%$ increased risk of severe COVID-19 per quintile of risk (for both: $\mathrm{OR}=1.03 ; 95 \%$ confidence interval $[\mathrm{CI}]=1.00,1.07 ; \mathrm{P}=0.05)$. The two PRS showed almost no ability to discriminate cases from controls, with an area under the receiver operating characteristic curve (AUC) for the 8-SNP PRS of $0.514(95 \% \mathrm{CI}=0.500,0.528)$ and an AUC for the 6-SNP PRS of $0.512(95 \% \mathrm{CI}=0.498,0.526)$.

Using population controls rather than people who are SARS-CoV-2 positive but are asymptomatic or have mild disease may have done more than bias associations towards the null, as suggested by Pairo-Castineira et al. ${ }^{1}$ If the associations seen using population controls were biased towards the null, we would expect the effects of loci identified with population controls to be stronger when using asymptomatic or mild SARS-CoV-2 positive controls. 
medRxiv preprint doi: https://doi.org/10.1101/2021.03.29.21254509; this version posted March 31, 2021. The copyright holder for this preprint (which was not certified by peer review) is the author/funder, who has granted medRxiv a license to display the preprint in It is made available under a CC-BY-NC-ND 4.0 International license .

This was not evident in our analyses nor was it evident in the COVID-19 Host Genetics Initiative ${ }^{8,9}$ Release 5 Manhattan plots (for the Hospitalized COVID-19 vs not-hospitalized COVID-19 and the Hospitalized COVID-19 vs population controls meta-analyses), where other than the 3p21.31 locus, the regions of association differ considerably. In the Hospitalized COVID-19 vs population controls meta-analysis, the only region of association is at 3p21.31, while for the Hospitalized COVID-19 vs population controls meta-analysis, 3 p21.31 was a clear region of association and there were six other regions of association (1q21.3, 9q34.2, 12q24.13, 17q21.33, 19p13.3, and 21q21.11; see Figure 1A and B). Interestingly, three of these regions (3p21.31, 9q34.2, and 12q24.13) overlapped with the Manhattan plot for all COVID-19 (i.e. infection): the COVID-19 vs population controls metaanalysis (see Figure 1B and C). The 3p21.31 locus has been identified previously in studies that used population controls, ${ }^{10,11}$ and rs71325088 and rs73064425 SNP identified by PairoCastineira et al. ${ }^{1}$ are both in $3 \mathrm{p} 21.31$. We also see an association for those two SNPs, albeit smaller in magnitude, using SARS-CoV-2 positive controls.

The use of population controls might mean that Pairo-Castineira et al. ${ }^{1}$ have identified SNPs associated with becoming infected with SARS-CoV-2 rather than SNPs associated with severe COVID-19, a limitation that has been identified by other authors using population controls. ${ }^{12}$ Researchers who use the results of large studies with population controls to inform their investigation of severe COVID-19 may therefore be wasting their time and resources. We urge care in the interpretation of results from large-scale studies that use population controls and invite discussion on this issue. 
medRxiv preprint doi: https://doi.org/10.1101/2021.03.29.21254509; this version posted March 31, 2021. The copyright holder for this preprint (which was not certified by peer review) is the author/funder, who has granted medRxiv a license to display the preprint in It is made available under a CC-BY-NC-ND 4.0 International license

Table 1. Unadjusted odds ratios per effect allele for the 12 SNPs

\begin{tabular}{clccccc}
\hline Chr & \multicolumn{1}{c}{ SNP } & $\begin{array}{c}\text { Reference } \\
\text { allele }\end{array}$ & $\begin{array}{c}\text { Effect } \\
\text { allele }\end{array}$ & OR & $95 \%$ Cl & P-value \\
\hline 3 & rs71325088 & T & C & 1.15 & $1.02,1.30$ & 0.02 \\
3 & rs73064425 & C & T & 1.17 & $1.03,1.32$ & 0.01 \\
6 & rs9380142 & G & A & 1.09 & $1.01,1.17$ & 0.03 \\
6 & rs143334143 & G & A & 0.97 & $0.85,1.11$ & 0.7 \\
6 & rs3131294 & A & G & 1.00 & $0.91,1.11$ & 0.9 \\
12 & rs6489867 & C & T & 0.96 & $0.89,1.03$ & 0.2 \\
12 & rs10735079 & G & A & 0.96 & $0.89,1.03$ & 0.2 \\
19 & rs2109069 & G & A & 1.05 & $0.97,1.13$ & 0.2 \\
19 & rs74956615 & T & A & 1.01 & $0.86,1.18$ & 0.9 \\
19 & rs11085727 & C & T & 1.02 & $0.95,1.10$ & 0.6 \\
21 & rs13050728 & C & T & 1.07 & $0.99,1.15$ & 0.07 \\
21 & rs2236757 & G & A & 1.06 & $0.98,1.14$ & 0.1 \\
\hline
\end{tabular}

Note: Chr, chromosome number; $\mathrm{Cl}$, confidence interval; OR, odds ratio per effect allele; SNP, singlenucleotide polymorphism. 
medRxiv preprint doi: https://doi.org/10.1101/2021.03.29.21254509; this version posted March 31, 2021. The copyright holder for this preprint (which was not certified by peer review) is the author/funder, who has granted medRxiv a license to display the preprint in It is made available under a CC-BY-NC-ND 4.0 International license.

A. Hospitalized COVID-19 vs not-hospitalized COVID-19 (B1_ALL_eur)

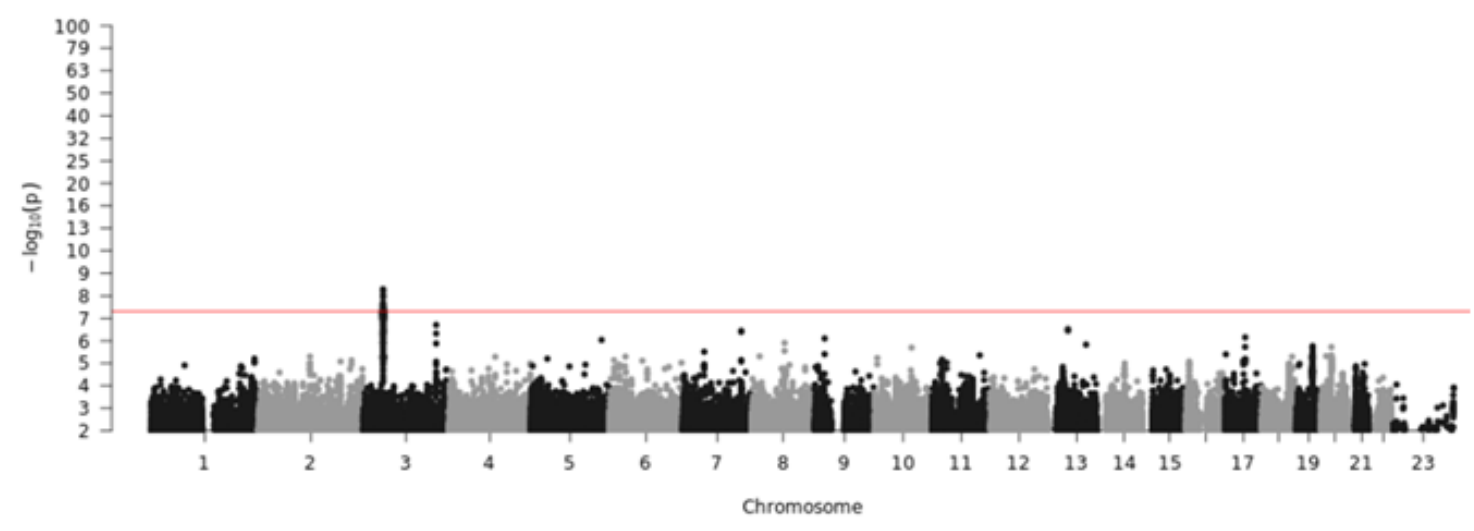

B. Hospitalized COVID-19 vs population controls (B2_ALL_eur)

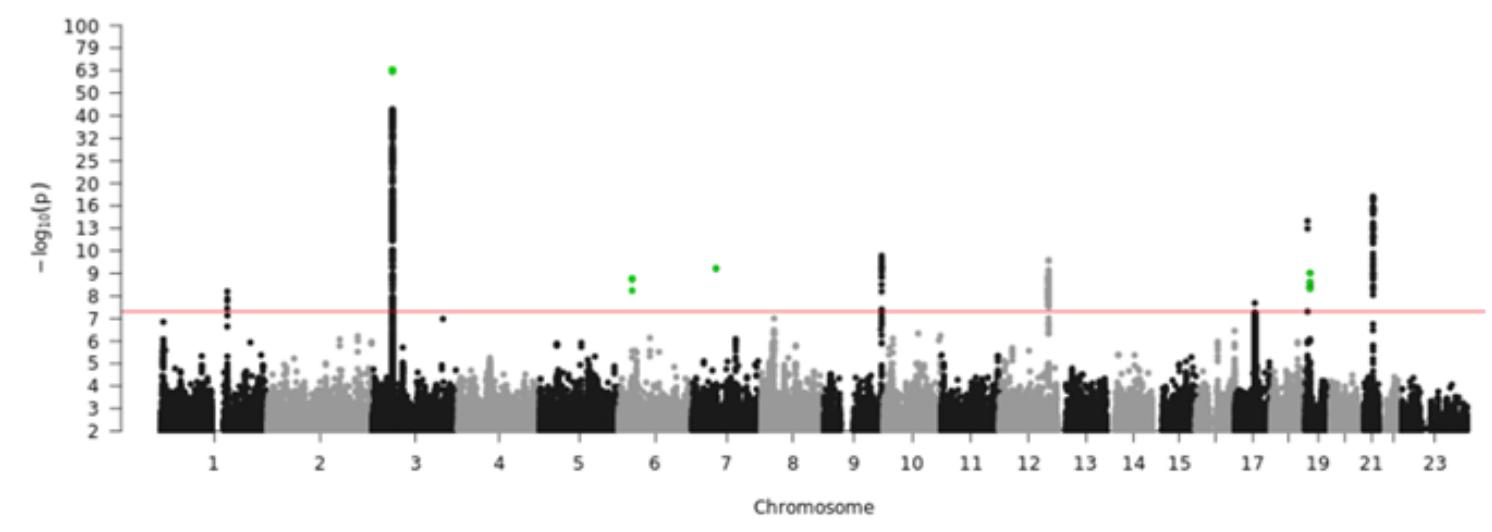

C. COVID-19 vs population controls (C2_ALL_eur)

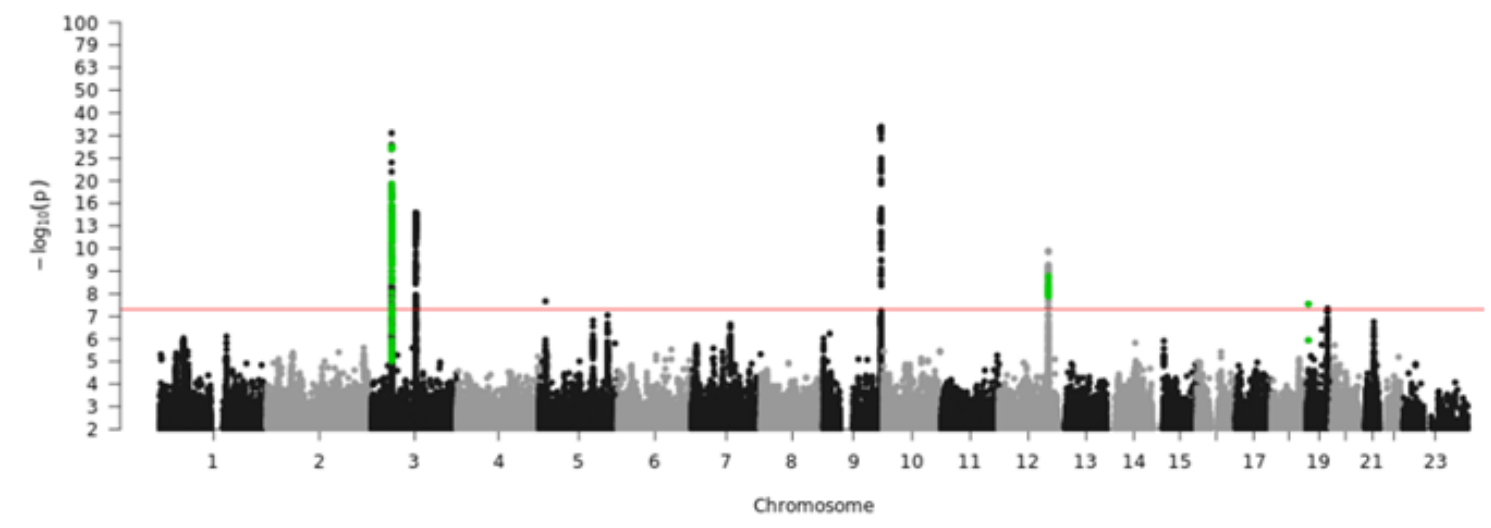

Figure 1. Manhattan plots from the COVID-19 Host Genetics Initiative Release 5 metaanalyses of (A) Hospitalized COVID-19 vs not-hospitalized COVID-19, Hospitalized COVID-19 vs population controls, and (C) COVID-19 vs population controls. 
medRxiv preprint doi: https://doi.org/10.1101/2021.03.29.21254509; this version posted March 31, 2021. The copyright holder for this preprint (which was not certified by peer review) is the author/funder, who has granted medRxiv a license to display the preprint in It is made available under a CC-BY-NC-ND 4.0 International license .

\section{References}

1 Pairo-Castineira, E. et al. Genetic mechanisms of critical illness in Covid-19. Nature 591, 92-98, doi:10.1038/s41586-020-03065-y (2021).

2 Bycroft, C. et al. The UK Biobank resource with deep phenotyping and genomic data. Nature 562, 203-209, doi:10.1038/s41586-018-0579-z (2018).

3 Sudlow, C. et al. UK biobank: an open access resource for identifying the causes of a wide range of complex diseases of middle and old age. PLoS Med 12, e1001779, doi:10.1371/journal.pmed.1001779 (2015).

UK Biobank. UK Biobank makes health data available to tackle COVID-19, <https://www.ukbiobank.ac.uk/2020/04/covid/> (2020).

5 Dite, G. S., Murphy, N. M. \& Allman, R. An integrated clinical and genetic model for predicting risk of severe COVID-19: A population-based case-control study. PLoS One 16, e0247205, doi:10.1371/journal.pone.0247205 (2021).

6 Oscanoa, J. et al. SNPnexus: a web server for functional annotation of human genome sequence variation (2020 update). Nucleic Acids Res. 48, W185-W192, doi:10.1093/nar/gkaa420 (2020).

7 Mealiffe, M. E. et al. Assessment of clinical validity of a breast cancer risk model combining genetic and clinical information. J Natl Cancer Inst 102, 1618-1627, doi:10.1093/jnci/djq388 (2010).

8 COVID-19 Host Genetics Initiative. The COVID-19 Host Genetics Initiative, a global initiative to elucidate the role of host genetic factors in susceptibility and severity of the SARS-CoV-2 virus pandemic. Eur. J. Hum. Genet. 28, 715-718, doi:10.1038/s41431-020-0636-6 (2020).

9 COVID-19 Host Genetics Initiative. COVID19hg GWAS meta-analyses round 5, <https://www.covid19hg.org/results/r5/> (2021). 
medRxiv preprint doi: https://doi.org/10.1101/2021.03.29.21254509; this version posted March 31, 2021. The copyright holder for this preprint (which was not certified by peer review) is the author/funder, who has granted medRxiv a license to display the preprint in It is made available under a CC-BY-NC-ND 4.0 International license .

10 Ellinghaus, D. et al. Genomewide association study of severe Covid-19 with respiratory failure. N. Engl. J. Med. 383, 1522-1534, doi:10.1056/NEJMoa2020283 (2020).

11 Shelton, J. F. et al. Trans-ethnic analysis reveals genetic and non-genetic associations with COVID-19 susceptibility and severity. medRxiv, doi:10.1101/2020.09.04.20188318, 7 September 2020, preprint: not peer reviewed.

12 Hernández Cordero, A. I. et al. Multi-omics highlights ABO plasma protein as a causal risk factor for COVID-19. Hum. Genet., doi:10.1007/s00439-021-02264-5 (2021). 
medRxiv preprint doi: https://doi.org/10.1101/2021.03.29.21254509; this version posted March 31, 2021. The copyright holder for this preprint (which was not certified by peer review) is the author/funder, who has granted medRxiv a license to display the preprint in It is made available under a CC-BY-NC-ND 4.0 International license .

\section{Ethics approval}

The UK Biobank has Research Tissue Bank approval (REC \#11/NW/0382) that covers analysis of data by approved researchers. All participants provided written informed consent to the UK Biobank before data collection began. This research has been conducted using the UK Biobank resource under Application Number 47401.

\section{Competing interests}

GSD, NMM, and RA are employees of Genetic Technologies Limited. Genetic Technologies Limited had no role in the conceptualization, design, data analysis, decision to publish or preparation of the manuscript.

\section{Author contributions}

All authors were involved in the conceptual development of this study. NMM and RA examined the Host Genetics Initiative meta-analysis results. GSD undertook data management and conducted the statistical analyses. All authors contributed to writing the first draft and reviewed and edited the manuscript. All authors have approved the final manuscript. 